\title{
Metallomics
}

Cite this: Metallomics, 2014 6,1014

Received 1st February 2014 Accepted 6th March 2014

DOI: $10.1039 / c 4 m t 00034 j$

www.rsc.org/metallomics

\section{Potent organometallic osmium compounds induce mitochondria-mediated apoptosis and S-phase cell cycle arrest in A549 non-small cell lung cancer cells}

\author{
Sabine H. van Rijt, ${ }^{a}$ Isolda Romero-Canelón, ${ }^{a}$ Ying Fu, ${ }^{a}$ Steve D. Shnyder ${ }^{\mathrm{b}}$ and \\ Peter J. Sadler*a
}

\begin{abstract}
The problems of acquired resistance associated with platinum drugs may be addressed by chemotherapeutics based on other transition metals as they offer the possibility of novel mechanisms of action. In this study, the cellular uptake and induction of apoptosis in A549 human non-small cell lung cancer cells of three promising osmium(॥) arene complexes containing azopyridine ligands, [Os $\left(\eta^{6}\right.$-arene)( $p$-R-phenylazopyridine) $\mathrm{X}_{\mathrm{PF}} \mathrm{F}_{6}$, where arene is $p$-cymene or biphenyl, $\mathrm{R}$ is $\mathrm{OH}$ or $\mathrm{NMe}_{2}$, and $\mathrm{X}$ is $\mathrm{Cl}$ or $\mathrm{l}$, were investigated. These complexes showed time-dependent (4-48 h) potent anticancer activity with highest potency after $24 \mathrm{~h}\left(\mathrm{IC}_{50}\right.$ values ranging from 0.1 to $\left.3.6 \mu \mathrm{M}\right)$. Cellular uptake of the three compounds as quantified by ICP-MS, was independent of their $\log P$ values (hydrophobicity). Furthermore, maximum cell uptake was observed after $24 \mathrm{~h}$, with evident cell efflux of the osmium after 48 and $72 \mathrm{~h}$ of exposure, which correlated with the corresponding $I_{50}$ values. The most active compound 2, [Os $\left(\eta^{6}\right.$-p-cymene)(NMe 2 -phenylazopyridine)l] $\mathrm{PF}_{6}$, was taken up by lung cancer cells predominately in a temperature-dependent manner indicating that energy-dependent mechanisms are important in the uptake of $\mathbf{2}$. Cell fractionation studies showed that all three compounds accumulated mainly in cellular membranes. Furthermore, compound $\mathbf{2}$ induced apoptosis and caused accumulation in the S-phase of the cell cycle. In addition, 2 induced cytochrome $c$ release and alterations in mitochondrial membrane potential even after short exposure times, indicating that mitochondrial apoptotic pathways are involved. This study represents the first steps towards understanding the mode of action of this promising class of new osmium-based chemotherapeutics.
\end{abstract}

\section{Introduction}

Lung cancer is the leading cause of cancer deaths in the Western World. Survival rates are poor with a 5-year mortality of about $90 \%$. Most patients face an intensive and invasive treatment regimen comprising surgery, chemotherapy, or radiotherapy, often combinations thereof. ${ }^{1}$ The platinum-based drug, cisplatin (CDDP) is a commonly used chemotherapeutic agent for the treatment of lung cancer. However, one of the major drawbacks of CDDP is acquired resistance of tumours towards the drug. To overcome this problem, CDDP is often given as a combination treatment with other chemotherapeutics such as etoposide, gemcitabine or paclitaxel. ${ }^{2,3}$ Anticancer drugs based

\footnotetext{
${ }^{a}$ Department of Chemistry, University of Warwick, Gibbet Hill Road, Coventry CV4 7AL, UK. E-mail: p.j.sadler@warwick.ac.uk; Fax: +44 (o)24 7652 3819; Tel: +44 (0)24 76523818

${ }^{b}$ Institute of Cancer Therapeutics, University of Bradford, Richmond Road, Bradford BD7 1DP, UK
}

on other transition metals may address the problems associated with acquired resistance to platinum drugs. Several other metal-based compounds with promising antitumor activity towards a wide range of tumours with novel mechanisms of action have been reported. ${ }^{4-7}$ In recent years, we and others have reported organometallic osmium(II) arene complexes with promising cancer cell cytotoxicity. ${ }^{8-11}$ Some of these osmium complexes are non-cross-resistant with CDDP toward some cancer cells, ${ }^{8,12,13}$ suggesting that they have a different mechanism of action and show potential for addressing the problem of intrinsic or acquired resistance towards CDDP. A particularly promising class of osmium(II) arene complexes containing azopyridine (azpy) ligand derivatives, $\left[\mathrm{Os}\left(\eta^{6}\right.\right.$-arene $)(p$-R-phenylazopyridine) $\mathrm{X}] \mathrm{PF}_{6}$, where arene is $p$-cymene or biphenyl, and $\mathrm{X}$ is $\mathrm{Cl}$ or $\mathrm{I}$, show nanomolar activity towards a large panel of cancer cell lines. ${ }^{8}$ In addition, some of these complexes exhibit low toxicity and negligible deleterious effects in a colon cancer tumour xenograft model, indicating that they may have a broad therapeutic window. ${ }^{14}$ Interestingly, the toxicity of these 
complexes can be modulated by manipulation of intracellular GSH levels. Antiproliferative activity can be partly inhibited by increasing GSH levels prior to drug exposure by pre-treating the cells with $N$-acetyl-L-cysteine, one of the precursors of GSH. ${ }^{8,15}$ In contrast, the potency of these metal-based compounds can be increased by co-administration of L-buthionine sulfoximine (L-BSO) which inhibits the synthesis of GSH. ${ }^{16}$

In this study, three compounds containing phenylazopyridine (azpy) ligands with dimethylaminyl $\left(\mathrm{NMe}_{2}\right)$ or hydroxyl $(\mathrm{OH})$ substitutions on the phenyl ring and iodido or chlorido leaving groups; $\left[\mathrm{Os}\left(\eta^{6}\right.\right.$-bip $)(p$-OH-azpy)I $] \mathrm{PF}_{6}(\mathbf{1}),\left[\mathrm{Os}\left(\eta^{6}-p\right.\right.$-cym $)$ $\left(p-\mathrm{NMe}_{2}\right.$-azpy)I $] \mathrm{PF}_{6}(2)$, and $\left[\mathrm{Os}\left(\eta^{6}-p\right.\right.$-cym $)\left(p-\mathrm{NMe}_{2}\right.$-azpy)Cl $] \mathrm{PF}_{6}$ (3) where bip is biphenyl and $p$-cym is $p$-cymene, were investigated in the A549 human non-small cell lung cancer cell line (Fig. 1). The structures of the complexes allow a comparison between the different leaving groups and substitutions on the pyridine ring. These complexes have already been shown to have nanomolar activity in ovarian, breast, colon, prostate and bladder human cancer cell lines. ${ }^{8}$ Here we show that three of them have potent activity in A549 cells that is dependent on exposure time. The mechanism by which A549 cells take up and internalize the osmium arene compounds is investigated by studying the time- and temperature-dependence of cell uptake, their hydrophobicity, and intracellular localisation. Moreover, the involvement of the mitochondrial apoptotic pathway in the induction of apoptosis by the most potent complex 2 is studied. This work represents the first steps towards understanding the mode of action of this promising class of chemotherapeutic agents.

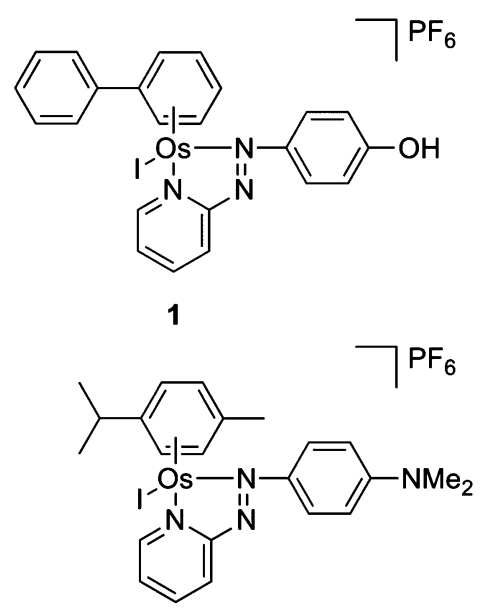

2

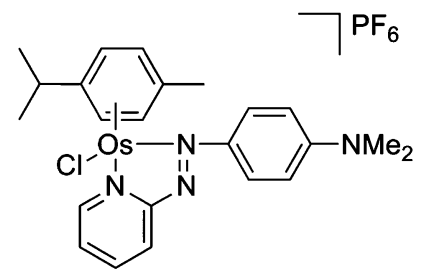

3

Fig. 1 Chemical structures of the organometallic osmium(॥) arene complexes studied in this work.

\section{Experimental}

\section{Materials}

1,4-Dihydrobiphenyl and the dimers $\left[\left(\eta^{6}-p \text {-cym }\right) \mathrm{OsCl}_{2}\right]_{2}$ and $\left[\left(\eta^{6} \text {-bip)OsCl }{ }_{2}\right]_{2}\right.$ were prepared by previously reported procedures. ${ }^{17}$ $\mathrm{OsCl}_{3} \cdot n \mathrm{H}_{2} \mathrm{O}$ was purchased from Alfa Aesar. All deuterated solvents and CDDP were obtained from Sigma Aldrich. Methanol was distilled over magnesium-iodine prior to use. Complexes 1-3 were synthesized and characterized as reported previously. ${ }^{8}$

\section{ICP-MS instrumentation and calibration}

ICP-MS analyses were carried out on an Agilent Technologies 7500 Series ICP-MS instrument. The water used for ICP-MS analysis was double deionised (DDW) using a USF Elga UHQ water deionizer. The osmium Specpure plasma standard (Alfa Aesar, 1000 ppm in $5 \% \mathrm{HCl}$ ) was diluted with DDW to $20 \mathrm{ppm}$. The standards for calibration were freshly prepared by diluting this stock solution with $3 \% \mathrm{HNO}_{3}$ in DDW. The concentrations used were 100, 60, 20, 10, 5, 4, 2, 1, 0.4 and $0.1 \mathrm{ppb}$. The detection limit was typically $30 \mathrm{ppt}$ $(n=10)$, and sensitivity $42200{ }^{189}$ Os ion counts for $100 \mathrm{ppb}$ of Os standard in helium mode and 9 ppt $(n=10)$, and sensitivity $270900{ }^{189}$ Os ion counts for 100 ppb of Os standard in no gas mode.

\section{Cell culture}

The human A549 non-small cell lung cancer cell line was obtained from the ECACC (European Collection of Animal Cell Culture, Salisbury, UK) and used between passages 5 and 15. The cells were maintained in RPMI 1640 media which was supplemented with $10 \%$ fetal calf serum, 1\% L-glutamine and $1 \%$ penicillin/streptomycin. All cells were grown at $310 \mathrm{~K}$ in a humidified atmosphere containing $5 \% \mathrm{CO}_{2}$, and passaged routinely when $80 \%$ confluence was reached.

\section{In vitro growth inhibition assay}

After plating, A549 cells were treated with Os ${ }^{\mathrm{II}}$ complexes on day 2, at concentrations ranging from $0.1 \mu \mathrm{M}$ to $100 \mu \mathrm{M}$. Stock solutions of the Os ${ }^{\mathrm{II}}$ complexes $(1 \mathrm{mM})$ were made up in $0.125 \%(\mathrm{v} / \mathrm{v})$ DMSO to assist dissolution ( $0.03 \%$ final concentration of DMSO per well in the 96-well plate). Negative controls were exposed to the same final DMSO concentration. The osmium stock solutions were analysed by ICP-MS to confirm metal content, with working solutions diluted from the stock solutions. Cells were exposed to the complexes for $4 \mathrm{~h}, 24 \mathrm{~h}$, or $48 \mathrm{~h}$, washed, supplied with fresh medium, allowed to grow for three doubling times $(72 \mathrm{~h})$, and then the protein content measured (proportional to cell survival) using the sulforhodamine $\mathrm{B}$ (SRB) assay. ${ }^{18}$ We also determined the antiproliferative activity of complex 2 under a second set of conditions which included seeding the A549 cells in 6-well plates and allowing $24 \mathrm{~h}$ of pre-incubation time in drug free-medium followed by 24,48 or $72 \mathrm{~h}$ of drug exposure at $310 \mathrm{~K}$ under humidified atmosphere. In this case, cells were not allowed to recover and the SRB assay was performed upon completion of the drug exposure period.

\section{Drug uptake and cell fractionation}

A549 cells were plated at a density of $3 \times 10^{6}$ cells per $100 \mathrm{~mm}$ Petri dish in $12 \mathrm{~mL}$ of culture medium on day 1 (three dishes 
were prepared per compound tested and three untreated control dishes in two independent set of experiments). On day 2 cells were exposed to the Os ${ }^{\mathrm{II}}$ arene complexes. Stock solutions $(0.5 \mathrm{mM})$ of osmium compounds were made up fresh in 5\% DMSO and saline before being diluted in medium to give a final concentration of $1 \mu \mathrm{M}(0.01 \% \mathrm{v} / \mathrm{v}$ final concentration of DMSO per well). Negative controls were exposed to the same final DMSO concentration. After $24 \mathrm{~h}$ of drug exposure, the drug-containing medium was removed; the cells were washed with PBS, trypsinised and the cell suspension counted. Half of the cells were centrifuged, washed with PBS and stored at $253 \mathrm{~K}$. The other half of the sample was used for cytosol, nucleus, membrane and cytoskeleton fractionation using the cell fractionation kit (Biovision, Mountain View, US) (fractionPREP ${ }^{\mathrm{TM}}$ ) according to the manufacturer's instructions. All samples were stored at $253 \mathrm{~K}$ until ICP-MS analysis for osmium content. For the time- and temperaturedependent cell uptake experiments, A549 cells were plated at a density of $3 \times 10^{6}$ cells per $100 \mathrm{~mm}$ Petri dish in $12 \mathrm{~mL}$ of culture medium on day 1 . On day 2 cells were exposed to complex 2 at a concentration of $1 \mu \mathrm{M}$ (prepared as stated previously) at $0.5,1,2$ and $4 \mathrm{~h}$ time intervals. After the indicated exposure times, cells were trypsinized and the cell suspension counted. The cells were centrifuged, washed with PBS and stored at $253 \mathrm{~K}$ until ICP-MS analysis for osmium content.

\section{ICP-MS analysis}

The whole cell pellets and cytosol/nucleus/membrane/cytoskeleton fractionation samples were digested as described below. To the cell pellets was added $0.4 \mathrm{~mL}$ and to the extracts $0.2 \mathrm{~mL}$ of freshly distilled $72 \% \mathrm{HNO}_{3}$ and the samples were transferred into wheaton v-vials ${ }^{\circledR}$ (Sigma Aldrich). The vials were heated in an oven at $373 \mathrm{~K}$ for $16 \mathrm{~h}$ to fully digest the samples, allowed to cool, and then each sample was transferred to a falcon tube. The vials were washed with DDW and the samples diluted 10 times with DDW to obtain $7.2 \% \mathrm{HNO}_{3}$ sample solutions.

\section{Live/dead assay using Annexin V}

The induction of apoptosis or necrosis was investigated in A549 cells using Annexin V FITC and propidium iodide double staining. Briefly, $2.5 \times 10^{5}$ cells were seeded per well in 6 -well plates. $24 \mathrm{~h}$ after seeding, control cells and cells treated with compound 2 at the indicated concentrations were incubated for 24 and $48 \mathrm{~h}$. Following exposure, the drug-containing medium was removed, and cells were washed, harvested and stained with Annexin V FITC and propidium iodide (Biovision, Annexin V-FITC Apoptosis Kit) according to the manufacturer's instructions. Control samples stained with just PI or Annexin V FITC were also included for compensation purposes. The samples were analysed using FACS Calibur ${ }^{\mathrm{TM}}$ flow cytometer running Cell Quest software (20000 events were collected from each sample).

\section{Cytochrome $c$ release and mitochondrial membrane potential assays}

The release of cytochrome $c$ into the cytosol of A549 cells exposed to complex 2 was investigated using the FlowCellect Cytochrome $c$ Kit from Merk Millipore according to the manufacturer's instructions. Briefly, cells were seeded in triplicate into 6-well plates and incubated in drug-free medium for $24 \mathrm{~h}$ before exposing them to complex 2 for 4 or $24 \mathrm{~h}$. After the drug exposure period, supernatants were removed by suction and cells were washed with cold PBS before being trypsinized and counted. Each sample was aliquoted into $500 \mu \mathrm{L}$ of a PBS solution containing $1.5 \times 10^{5}$ cells, permeabilized, fixed and blocked before adding the anti-IgG1-FITC isotype control or the anti-cytochrome $c$-FITC antibody to each sample. After further blocking treatment, samples were analyzed in a Beckton Dickinson FACScan. The reduction of green fluorescence in the FL1 channel indicated the release of cytochrome $c$ into the cytosol.

To determine the mitochondrial membrane potential by microscopy, A549 cells were grown on chamber slides ( $\mathrm{Nunc}^{\mathrm{TM}}$ Lab-Tek $\left.{ }^{\mathrm{TM}}\right) .24 \mathrm{~h}$ after plating, the cells were treated with $2.5 \mu \mathrm{M}$ complex 2. After 24 or $48 \mathrm{~h}$ incubation with 2, the drugcontaining medium was removed, cells were washed and stained with MitoCapture Apoptosis Detection Kit (Biovision) according to the manufacturer's instructions. The live cells were imaged on a LEICA SP5 confocal microscope.

\section{Cell cycle}

A549 cells were seeded at a density of $2.5 \times 10^{5}$ cells per well in a 6-well plate and grown for $24 \mathrm{~h}$. After the $24 \mathrm{~h}$, cells were treated with complex 2 with the indicated concentrations. Cells were collected after 24 or $48 \mathrm{~h}$ of incubation and washed with PBS. Cells were fixed with $70 \%$ ethanol and stored at $253 \mathrm{~K}$. For analysis, cells were transferred into PBS, incubated with RNase $\left(0.2 \mathrm{mg} \mathrm{mL}^{-1}\right)$ and propidium iodide $\left(0.05 \mathrm{mg} \mathrm{mL}^{-1}\right)$ for $40 \mathrm{~min}$ at $310 \mathrm{~K}$ and then analysed by flow cytometry using a FACS Calibur $^{\mathrm{TM}}$ flow cytometer as above. The resulting DNA histograms were quantified using the FlowJo software (version 7.2.5).

\section{Determination of partition coefficient, $\log P$}

Octanol-saturated water (OSW), and water-saturated octanol (WSO) were prepared using analytical grade octanol (Sigma) and $0.3 \mathrm{M} \mathrm{NaCl}$ for chloride complex 3 and $0.3 \mathrm{M}$ NaI solution was used for the iodide complexes $\mathbf{1}$ and 2. Aliquots of stock solutions of osmium complexes in OSW were added to equal volumes of WSO and shaken in an IKA Vibrax VXC basic shaker for $4 \mathrm{~h}$ at $500 \mathrm{~g} \mathrm{~min}^{-1}$. After partition, the aqueous and octanol layers were carefully separated into test tubes for osmium analysis. Dilutions of the aqueous samples before and after partitioning were made with $3 \% \mathrm{HNO}_{3}$ to the appropriate range for analysis by ICP-MS calibrated with aqueous standards (Os: 1-100 ppb). These procedures were carried out at ambient temperature (ca. $298 \mathrm{~K}$ ). Partition coefficients of $\mathrm{Os}^{\mathrm{II}}$ arene complexes were calculated using the equation $\log P_{\text {oct }}=$ $\log \left([\text { Os }]_{\text {oct }} /[\text { OS }]_{\text {aq }}\right)$.

\section{Results and discussion}

\section{Synthesis}

Osmium arene compounds 1-3 (Fig. 1) were prepared via their respective I- or Cl-bridged dimers, $\left[\left(\eta^{6} \text {-arene }\right) \mathrm{OsX}_{2}\right]_{2}$ where 
arene $=$ biphenyl (bip) or $p$-cymene $(p$-cym) and $\mathrm{X}=\mathrm{I}$ or $\mathrm{Cl}$, as previously reported, with over $95 \%$ purity. $^{8}$

\section{Cytotoxicity}

The anticancer activity of compounds 1-3 in A549 cells at different exposure times (4, 24 and $48 \mathrm{~h}$ ) was evaluated after three doubling recovery times $(72 \mathrm{~h})$ in non-drug containing medium (Table 1). The cytotoxicity of these compounds under these conditions after $24 \mathrm{~h}$ has been reported by our laboratory previously and the data obtained here demonstrated similar activity. ${ }^{8}$ All three compounds showed potent activity with $\mathrm{IC}_{50}$ values of between 0.17 and $35.7 \mu \mathrm{M}$. Compounds 1 and 2 especially showed high anticancer activity, on the order of 6-10× more potent compared to cisplatin under the same testing conditions. The $\mathrm{IC}_{50}$ values of the osmium compounds were dependent on the exposure time, whereas the activity of CDDP was unaffected over the period 4 to $48 \mathrm{~h}$ (Table 1). The highest activity for all compounds was seen after $24 \mathrm{~h}$ of exposure; potency follows the order $\mathbf{2}>\mathbf{1}>\mathbf{3}$ where compound $\mathbf{2}$ is the most potent with an $\mathrm{IC}_{50}$ value of $0.17 \mu \mathrm{M}$ and complex 3 , the chlorido analogue of the iodido complex 2 , is the least active. After $4 \mathrm{~h}$ of cell exposure, iodido compounds $\mathbf{1}$ and $\mathbf{2}$ already show high cytotoxic activity. After $48 \mathrm{~h}$ of exposure, the $\mathrm{IC}_{50}$ values of all three compounds had increased. These compounds are known to be stable under aqueous conditions, ${ }^{8}$ suggesting that the $\mathrm{IC}_{50}$ values do not diminish over-time because of chemical decomposition. These data suggest that optimisation of the incubation time for this class of drugs is vital to obtain maximum cytotoxic activity. Iodido compounds 1 and $\mathbf{2}$ show very similar toxicity despite their different arenes (biphenyl and $p$-cymene) and substituents on the phenyl ring ( $\mathrm{OH}$ and $\mathrm{NMe}_{2}$, respectively). This, in combination with the large difference in toxicity between complex 2 and its chlorido analogue compound 3, suggests that for these complexes the halido monodentate ligand plays an important role in the mechanism of action. Indeed, we have previously reported osmium complexes of the type $\left[\mathrm{Os}\left(\eta^{6}\right.\right.$-arene)(azpy-R)I] $\mathrm{PF}_{6}$, where changing the monodentate leaving group from chloride to iodide had a dramatic effect on their potency. ${ }^{15,19}$ Interestingly, the iodido osmium arene complexes are remarkably inert towards ligand substitution which seems to indicate that the mechanism of cytotoxicity involves ligand-based redox reactions.

The initial cytotoxicity assays were performed in 96-well plates and included a $72 \mathrm{~h}$ recovery period in drug-free medium.

Table 1 In vitro growth inhibition of A549 cells for complexes 1-3 and cisplatin (CDDP) as control at different exposure times, values are given as $1 C_{50}(\mu \mathrm{M})$. Cells were grown in 96 -well plates and allowed to recover for 3 doubling times $(72 \mathrm{~h}$ )

\begin{tabular}{lrlr}
\hline & \multicolumn{3}{l}{$\mathrm{IC}_{50}{ }^{a}(\mu \mathrm{M})$} \\
\cline { 2 - 4 } Compound & \multicolumn{1}{c}{$4 \mathrm{~h}$} & $24 \mathrm{~h}$ & \multicolumn{1}{c}{$48 \mathrm{~h}$} \\
\hline $\mathbf{1}$ & $1.55 \pm 0.21$ & $0.31 \pm 0.02$ & $1.68 \pm 0.14$ \\
$\mathbf{2}$ & $0.85 \pm 0.15$ & $0.17 \pm 0.01$ & $0.32 \pm 0.03$ \\
$\mathbf{3}$ & $33.95 \pm 1.50$ & $3.64 \pm 0.23$ & $35.73 \pm 2.32$ \\
CDDP & $1.92 \pm 0.11$ & $1.78 \pm 0.15$ & $1.79 \pm 0.25$
\end{tabular}

${ }^{a}$ Each value represents the mean \pm SD for three independent experiments.

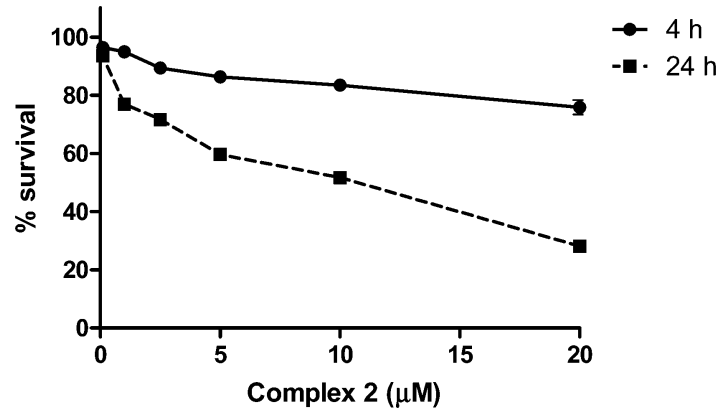

Fig. 2 In vitro growth inhibition for compound 2 in A549 cells after 4 and $24 \mathrm{~h}$ of exposure with cell culture conditions used for cell uptake, cell cycle and apoptosis studies. Under these conditions there was no recovery period included. In addition, increased cell numbers and decreased drug media volumes were used compared to the experiment as reported in Table 1.

We also assayed the cytotoxicity of compound 2 under the same culture conditions as were used for cell uptake, cell cycle and apoptosis studies (i.e. larger culture plates and no recovery period). The cytotoxicity of 2 was much lower under these conditions (Fig. 2). This may be explained by the reduced drugto-cell ratio, and lack of opportunity for the cells to recover.

\section{$\log P$ and cellular uptake}

The octanol-water partition coefficient ( $\log P$ value) is routinely used to relate anticancer activity and hydrophobicity for (metalbased) drugs. For several classes of anticancer metal complexes

A

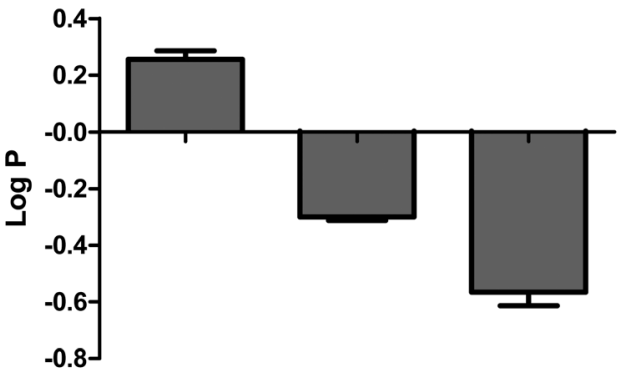

(1)

(2)

(3)

\section{Complex}

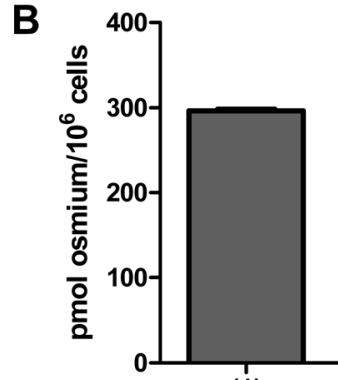

(1)

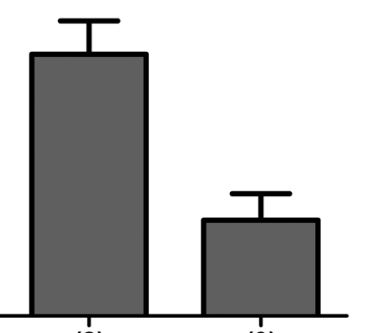

(2) Complex
Fig. 3 Hydrophobicity and cellular uptake of compounds 1,2 and 3. (A) $\log P$ values for complexes $1-3$. (B) Cellular osmium concentrations determined in A549 cells after $24 \mathrm{~h}$ exposure to $1 \mu \mathrm{M}$ of complex 1, 2 and 3 . Results are mean of six independent experiments and are expressed as mean $\pm \mathrm{SD}$. 
A

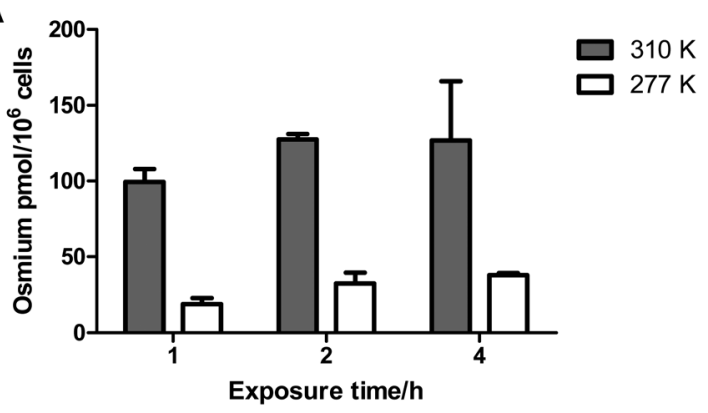

B

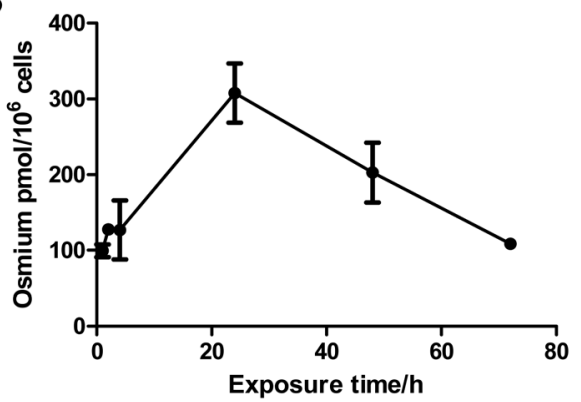

Fig. 4 Time- and temperature-dependent cellular uptake of complex 2 in A549 cells. (A) Cellular osmium concentrations determined after 0.5, 2 and $4 \mathrm{~h}$ exposure to $1 \mu \mathrm{M}$ of complex 2 at $277 \mathrm{~K}$ and $310 \mathrm{~K}$. (B) Cellular osmium concentrations determined after $0.5,2,4,24,48$ and $72 \mathrm{~h}$ exposure to $1 \mu \mathrm{M}$ of complex 2 . Results are mean of three independent samples and are expressed as mean \pm SD. a positive correlation between hydrophobicity and cytotoxicity has been reported. ${ }^{20-22}$ To assess the hydrophobicity of these osmium complexes, the partition coefficients $(\log P)$ were determined in octanol-water containing $300 \mathrm{mM}$ sodium chloride or sodium iodide in order to suppress hydrolysis. The $\log P$ values (Fig. 3A) increase in the order of $3<2<1$ with values of $-0.57 \pm 0.05$ for $3,-0.30 \pm 0.01$ for 2 and $0.26 \pm 0.03$ for $\mathbf{1}$.

Next, the cellular uptake of compounds 1-3 after $24 \mathrm{~h}$ was determined to assess whether the hydrophobicity of the compounds (as measured by $\log P$, Fig. $3 \mathrm{~A}$ ) correlated with the amount of compound taken up by the cell. The highest intracellular levels of osmium were observed after exposure to complex 1 $\left(296.5 \pm 2.0 \mathrm{pmol}\right.$ Os per $10^{6}$ cells $)$ and $2(307.8 \pm 38.9 \mathrm{pmol}$ Os per $10^{6}$ cells), and much less for least hydrophobic complex 3 $\left(112.2 \pm 31.2\right.$ pmol Os per $10^{6}$ cells) (Fig. $\left.3 \mathrm{~B}\right)$. The cellular uptake follows the order 1-2 $>3$, which does not correlate with their respective $\log P$ values (Fig. 3A and B). Surprisingly, substituting the iodide (2) by chloride (3) results in ca. 3 times less cellular uptake of osmium, indicating that the halogen plays an important role in the mechanism of cell uptake for these complexes. Although the $\log P$ values for $\mathbf{1}$ and $\mathbf{2}$ are quite different they are taken up into cells to a similar extent. The mechanism by which cellular uptake takes place needs to be considered as well and so hydrophobicity may not be the only parameter important for cellular uptake of these complexes. In order to assess the importance of energy-dependent cellular uptake mechanisms, the temperature dependence of the cellular accumulation of complex 2 as a function of time ( $t=1,2$ and $4 \mathrm{~h})$
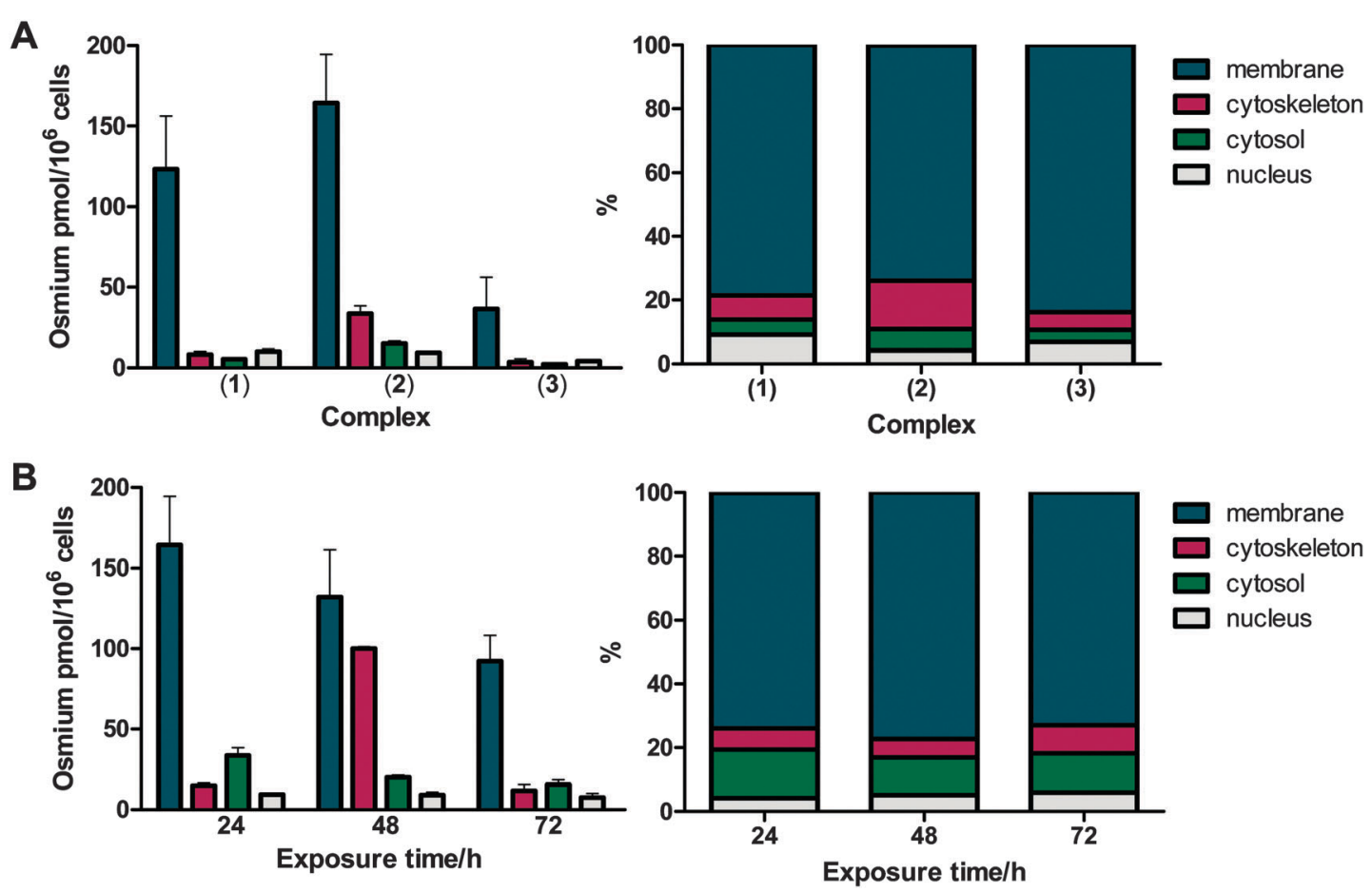

Fig. 5 Cellular distribution. (A) Concentration (left panel) and percentage (right panel) of osmium accumulating in nucleus, cytosol, cytoskeleton and membrane fractions in A549 lung cells after $24 \mathrm{~h}$ exposure to $1 \mu \mathrm{M}$ of 1-3. (B) Concentration (left panel) and percentage (right panel) of osmium accumulating in nucleus, cytosol, cytoskeleton and membrane fractions (pmol Os per $10^{6}$ cells) in A549 cells after 24,48 and $72 \mathrm{~h}$ exposure to $1 \mu \mathrm{M}$ of 2 . Results are mean of three independent experiments and are expressed as mean $\pm S D$ 
was investigated (Fig. 4A). At the low temperature of $277 \mathrm{~K}$, complex 2 was taken up by the cells to a reduced extent compared to the uptake observed at $310 \mathrm{~K}$ with levels of $37.8 \pm 0.5$ pmol Os per $10^{6}$ cells after $4 \mathrm{~h}$ at $277 \mathrm{~K}$ and $126.8 \pm 38.8$ pmol Os per $10^{6}$ cells at $310 \mathrm{~K}$. This shows that a quarter of the total Os taken up into the cells can be attributed to passive diffusion (energy-independent routes), and more than one mechanism is responsible for the uptake of 2. We have observed a similar behavior for analogous $\mathrm{Ru}$ half-sandwich complexes containing iminopyridine ligands. In the latter case, the iodido derivatives were taken up partly via passive diffusion, while this was not observed for the chlorido derivatives. ${ }^{23}$ Other metal complexes are known to be taken up partly via passive diffusion in addition to energydependent routes, these include vanadium complexes, ${ }^{21}$ copper bis(thiosemicarbazonato) complexes, ${ }^{24}$ and, bis(cyclometalated) iridium(III) polypyridine complexes. ${ }^{25}$

The reduction of cell uptake of 2 by $c a$. $75 \%$ at lower temperatures indicates that the uptake mechanism mainly involves energy-dependent routes. It would be interesting to establish which energy-dependent cell uptake route(s) is(are) responsible for the cellular uptake of complex 2 and related compounds. Such knowledge would aid the design of new compounds as well as help clarify their mechanism of action. It is likely that more pathways are involved, as observed previously for analogous ruthenium complexes. ${ }^{23}$

To help explain the exposure-time dependence of $\mathrm{IC}_{50}$ values, the cellular uptake for 2 , the most potent complex was investigated as a function of time $(t=0.5,2,4,24,48$ and $72 \mathrm{~h})$ (Fig. 4B). Cellular uptake was fast with significant uptake after only $0.5 \mathrm{~h}$ of exposure, explaining the observed low $\mathrm{IC}_{50}$ values after $4 \mathrm{~h}$ of exposure (Table 1). The maximum cell uptake was reached after $24 \mathrm{~h}$ exposure ( $307.8 \pm 38.8$ pmol Os per $10^{6}$ cells), while after $48 \mathrm{~h}$ and $72 \mathrm{~h}$ of exposure to 2 , the amount of osmium decreased markedly to $202.8 \pm 39.5$ pmol Os per $10^{6}$ cells and $108.5 \pm 5.6$ pmol Os per $10^{6}$ cells, respectively. This suggests that cellular efflux is an important factor in the cellular processing of these drugs and may arise from the activation of detox pumps such as PgP after certain exposure times, as a mechanism for cell recovery. This may explain why the $\mathrm{IC}_{50}$ values at longer exposure times of $48 \mathrm{~h}$ are not as low as those found after only $24 \mathrm{~h}$ of exposure.

\section{Cellular distributions}

The distribution of the osmium in isolated cell fractions (membrane, cytoskeleton, cytosol and nucleus) was determined after $24 \mathrm{~h}$ exposure to complexes 1-3 (Fig. 5A). The cellular distribution for all three compounds is very similar with $74-80 \%$ of osmium content localising in the membrane, $4-15 \%$ in the cytosol, 4-9\% in the nucleus and 6-8\% in the cytoskeleton fraction (Fig. 5A, right panel). A surprisingly high amount of osmium was detected in the membrane fraction, which also includes mitochondrial membranes.

The cellular distribution of complex 2 was also studied over the periods $t=24,48$ and $72 \mathrm{~h}$ (Fig. 5B). The overall amount of osmium in the cells decreased significantly over time as was observed in the uptake experiments of 2 in the whole cell (Fig. 5B). Interestingly, the amount of osmium from 2 that had localised in the nucleus and cytoskeleton remained approximately the same (with values of 7.6-9.4 pmol Os per $10^{6}$ cells and 9.8-14.8 pmol Os per $10^{6}$ cells, respectively), whereas the amount of osmium in the cytosol and membrane fractions decreased after $72 \mathrm{~h}$ to about half of the amount found after $24 \mathrm{~h}$ (with values of $33.6 \pm 4.8 \mathrm{pmol}$ Os per $10^{6}$ cells after $24 \mathrm{~h}$ to $15.63 \pm 3.02 \mathrm{pmol}$ Os per $10^{6}$ cells after $72 \mathrm{~h}$ in the cytosol, and $164.3 \pm 30.4 \mathrm{pmol}$ Os per $10^{6}$ cells after
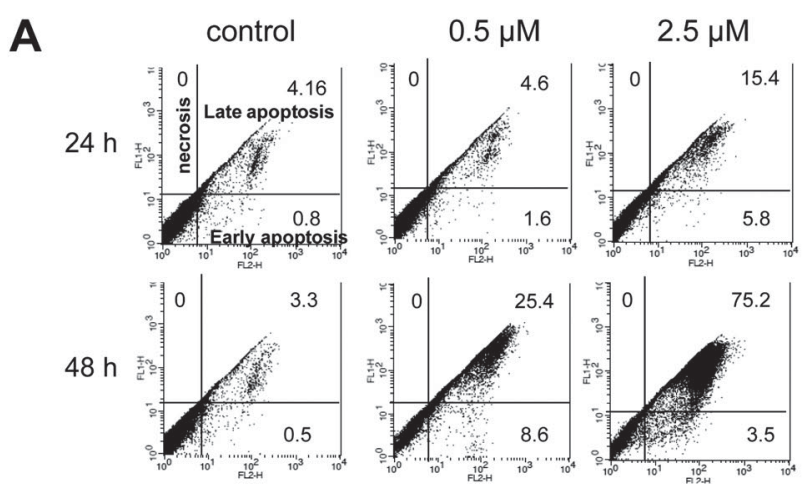

B
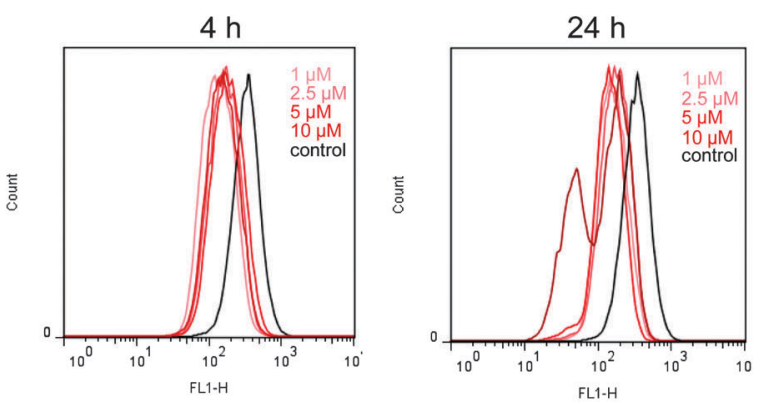

C
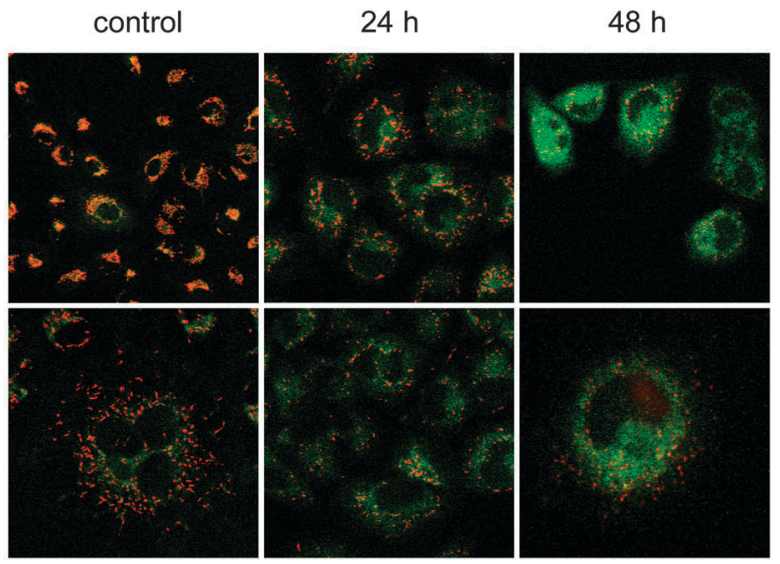

Fig. 6 Induction of apoptosis by compound 2. (A) Flow cytometric analysis of apoptosis/necrosis cell death using Annexin V-FITC/PI staining of A549 cells treated with complex $\mathbf{2}$. Percentages of cells in each quadrant are given. Data are the representative of one of two individual experiments. (B) The ability of complex $\mathbf{2}$ to induce cytochrome $c$ release by determined by FACS analysis. (C) Disruption of the mitochondrial membrane potential at 24 and 48 h of drug exposure visualized by a cationic dye that fluoresces differently in healthy cells (bright red) versus cells that contain mitochondria with a disrupted membrane potential (green fluorescence in the cytosol). Top row $\times 20$, bottom row $\times 40$ magnification. 
$24 \mathrm{~h}$ and $92.2 \pm 16.12 \mathrm{pmol}$ Os per $10^{6}$ cells after $72 \mathrm{~h}$ in the membrane) accounting for the efflux observed in the timedependent cell uptake studies.

\section{Apoptosis}

The ability of compound 2 to promote apoptosis/necrosis in A549 cells was determined by flow cytometry after staining the cells with Annexin-V-FITC and propidium iodide (PI). Externalisation of PS (phosphatidylserine) from the inner face of the plasma membrane to the cell surface is a hallmark of early apoptosis. The FITC labelled Annexin-V binds to PS, resulting in green fluorescence of early apoptotic cells. In later stages of apoptosis, PI enters the cell and binds strongly to DNA resulting in a strong red fluorescence. Cells in later apoptotic phases will therefore have both green and red fluorescence. Treatment of the A549 cells with compound 2 for $24 \mathrm{~h}$ or $48 \mathrm{~h}$ resulted in an increase in late stage apoptotic cells (upper right quadrant corner in Fig. 6A). None of the treated cells were necrotic (containing just PI staining, upper left quadrant) and few cells were in the early apoptotic stage (just Annexin-V-FITC staining, lower right quadrant). These data therefore show that compound 2 induces cell death via apoptotic pathways and does not induce necrosis.

\section{Mitochondria-induced apoptosis}

Since we observed a high amount of drug accumulation in the cell membrane fractions and since these fractions contain a large quantity of mitochondrial membranes, we next investigated whether the most potent anticancer compound (2) acts on mitochondrial pathways.

Cytochrome $c$ is released from mitochondria during the early stages of apoptosis and is a central event in apoptotic signalling. ${ }^{26}$
The ability of compound 2 to induce the release of cytochrome $c$ was investigated at early time-points ( 4 and $24 \mathrm{~h}$ ). After $4 \mathrm{~h}$, compound 2 was able to induce cytochrome $c$ release even at the lowest dose tested of $1 \mu \mathrm{M}$ (Fig. 6B). Previously no cell death was observed at any of the doses tested at $4 \mathrm{~h}$ (Fig. 2), indicating that compound 2 is already acting on mitochondria at low nontoxic doses, at early time-points prior to phenotypic detection of cell death. Also after $24 \mathrm{~h}$, an induction of cytochrome $c$ release could be observed after exposure to the lowest dose of $1 \mu \mathrm{M}$. Moreover, at the highest dose tested $(10 \mu \mathrm{M})$ an additional peak due to the appearance of an apoptotic cell population was visible (Fig. 6B).

Next we assessed whether compound 2 was also able to alter the mitochondrial transmembrane potential, another measure for mitochondrial health. Disruption of the mitochondrial membrane potential could be observed with confocal microscopy by the use of Mitotracker, a dye that can only aggregate in healthy mitochondria, fluorescing red. In apoptotic cells, the dye cannot aggregate in the mitochondria and remains in the cytosol, fluorescing green. In the control cells most of the dye had accumulated in the mitochondria giving off a bright red fluorescence, showing that the cells had healthy mitochondria (Fig. 6C). Cells treated with complex 2 for $24 \mathrm{~h}$ showed an increase in green fluorescence compared to the control cells indicating the disruption of the mitochondrial transmembrane potential. After $48 \mathrm{~h}$ most of the mitochondria in the cells had disrupted mitochondrial membrane potentials, as demonstrated by the observation of mainly green fluorescence (Fig. 6C).

Altogether, these data indicate that mitochondrial apoptotic pathways are involved in the mechanism of action of complex 2. Previously we found that osmium arene complexes containing picolinate chelating ligands accumulate in mitochondria and
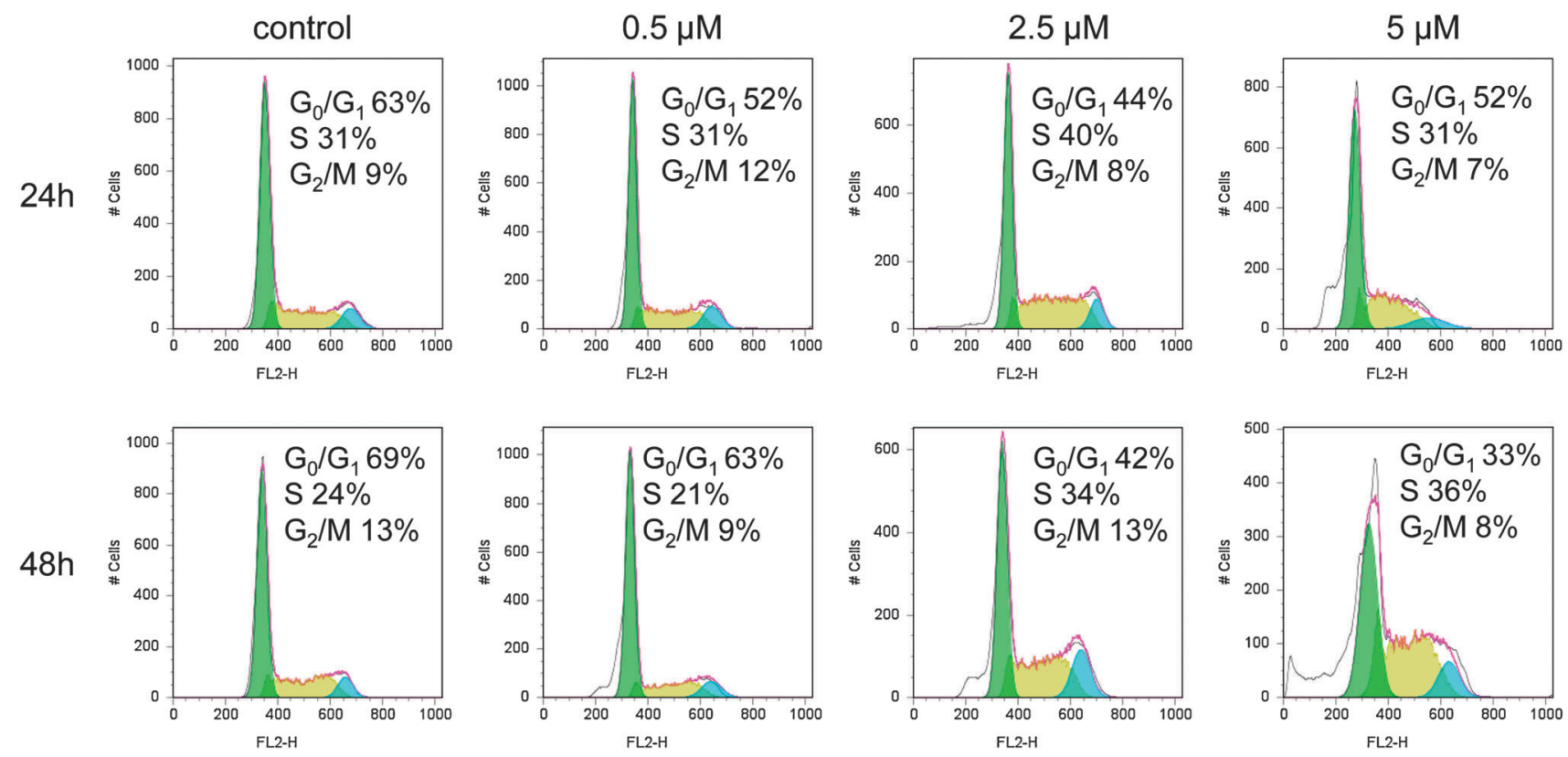

Fig. 7 Effects increasing concentrations of complex 2 on cell cycle distribution of $A 549$ cells at the indicated times. Percentages of cells in $G_{0} / G_{1}, S$ and $\mathrm{G}_{2} / \mathrm{M}$ phase are indicated. 
are able to alter the morphology of the cristae. ${ }^{27}$ There are a number of reports on transition metal complexes that can induce cell death by acting on mitochondrial pathways; these include ruthenium and iridium complexes and recently also similar observations for the triosmium cluster $\left(\left[\mathrm{Os}_{3}(\mathrm{CO})_{10}(\mu-\mathrm{H})(\mu-\mathrm{S}) \mathrm{C}_{9} \mathrm{H}_{6} \mathrm{~N}\right]\right) .^{28-30}$ Interestingly, a family of lipophilic, cationic $\mathrm{Au}(\mathrm{I})$ complexes of $\mathrm{N}$-heterocyclic carbenes (NHCs) was shown to accumulate selectively in the mitochondria and inhibit thioredoxin reductase. ${ }^{31}$ Targeting mitochondria in cancer cells appears to be a promising strategy, since enhanced mitochondrial stability and resistance to apoptosis induction caused by the upregulation of prosurvival proteins from the Bcl-2 family has been observed in a variety of tumours. ${ }^{32}$ In addition, since these compounds act on novel pathways compared to the commonly used chemotherapeutic drug CDDP, they offer promise in overcoming CDDP-acquired tumour resistance and may therefore be beneficial in combination treatment.

\section{Cell cycle}

The effect of increasing concentrations of 2 on cell cycle distribution of A549 cells after 24 and $48 \mathrm{~h}$ was investigated. After $24 \mathrm{~h}$, cells treated with $0.5 \mu \mathrm{M}$ complex did not show a considerable difference from the control cells. At higher concentrations, however, an increase in the amount of cells in the S-phase was observed (Fig. 7). A subset of cells treated with $2.5 \mu \mathrm{M}$ of 2 had undergone apoptosis, as indicated by the appearance of a sub- $\mathrm{G}_{0} / \mathrm{G}_{1}$ peak. The biggest effect was observed after $48 \mathrm{~h}$ of exposure to $5 \mu \mathrm{M}$ of 2 where a significant accumulation of the cells in the $\mathrm{S}$ phase was observed.

S-phase cell cycle arrest in cancer cells may be advantageous in providing differential toxicity since A549 cancer cells have shorter doubling times compared to healthy cells. Several anticancer agents are known to induce S-phase arrest in different types of human cancer cells, including cisplatin, ${ }^{33,34}$ mitomycin $\mathrm{C},{ }^{35,36}$ hydroxyurea, ${ }^{37}$ and the polyphenolic anticancer agent resveratrol. ${ }^{38,39}$ Several anticancer agents are known to inhibit topoisomerase activity and other key enzymes in DNA duplication. $^{40}$ It will be interesting to investigate further mechanisms of S-phase arrest induced by 2 .

\section{Conclusions}

In this work, three potent osmium arene phenylazopyridine complexes were investigated for their modes of cellular uptake, their cellular distribution, ability to cause cell cycle arrest, induction of apoptosis, and involvement in mitochondrial apoptotic pathways in A549 non-small cell lung cancer cells.

Iodido complexes 1 and 2 show potent anticancer activity in the A549 cell line after $24 \mathrm{~h}$ incubation, that is $c a$. 6-10× more potent than cisplatin. Furthermore, after $4 \mathrm{~h}$ of exposure, these iodido complexes already showed high potency in the A549 cell line, attributable to their rapid cellular uptake. The cell uptake of the complexes did not correlate with their respective hydrophobicities, as measured by their $\log P$ values. This can be explained by the temperature (energy)-dependent cellular uptake of 2 ; only $\sim 25 \%$ of complex 2 was taken up by an energyindependent mechanism (i.e. passive diffusion), in which hydrophobicity can play a major role.

Drug efflux was observed after 48 and $72 \mathrm{~h}$ of drug exposure, perhaps explaining why the $\mathrm{IC}_{50}$ values of the complexes are highest after $24 \mathrm{~h}$ of exposure. All three compounds accumulate in cell membranes to a large extent, consistent with the rapid promotion of cell death by acting on mitochondrial pathways. Indeed, compound 2 was able to cause cytochrome $c$ release and disrupt the mitochondrial membrane potential after 4 and $24 \mathrm{~h}$ of incubation at low doses. In addition, cells exposed to 2 accumulated in the S-phase in a concentration-dependent manner. The data obtained here represent the first steps towards understanding the mechanism of action of these novel osmium arene complexes containing phenylazopyridine derivatives.

\section{Acknowledgements}

This research was supported by the EPSRC (EP/H500308/1), ERC (grant no. 247450), University of Warwick IAS (fellowship for IRC) and Science City (ERDF/AWM). We thank Bushra Qamar for excellent technical assistance with cell culture and also acknowledge participation in the EU COST Actions D39 and CM1105 which enabled the exchange of ideas in the field of anticancer metallodrugs with several European colleagues.

\section{References}

1 M. Reck, D. F. Heigener, T. Mok, J. C. Soria and K. F. Rabe, Lancet, 2013, 382, 709-719.

2 A. Ardizzoni, G. Antonelli, F. Grossi, L. Tixi, M. Cafferata and R. Rosso, Ann. Oncol., 1999, 10(suppl 5), S13-S17.

3 R. Califano, A. Z. Abidin, R. Peck, C. Faivre-Finn and P. Lorigan, Drugs, 2012, 72, 471-490.

4 A. Bergamo, C. Gaiddon, J. H. Schellens, J. H. Beijnen and G. Sava, J. Inorg. Biochem., 2012, 106, 90-99.

5 K. B. Garbutcheon-Singh, M. P. Grant, B. W. Harper, A. M. Krause-Heuer, M. Manohar, N. Orkey and J. R. AldrichWright, Curr. Top. Med. Chem., 2011, 11, 521-542.

6 U. Jungwirth, C. R. Kowol, B. K. Keppler, C. G. Hartinger, W. Berger and P. Heffeter, Antioxid. Redox Signaling, 2011, 15, 1085-1127.

7 S. H. van Rijt and P. J. Sadler, Drug Discovery Today, 2009, 14, 1089-1097.

8 Y. Fu, A. Habtemariam, A. M. Pizarro, S. H. van Rijt, D. J. Healey, P. A. Cooper, S. D. Shnyder, G. J. Clarkson and P. J. Sadler, J. Med. Chem., 2010, 53, 8192-8196.

9 S. H. van Rijt, A. J. Hebden, T. Amaresekera, R. J. Deeth, G. J. Clarkson, S. Parsons, P. C. McGowan and P. J. Sadler, J. Med. Chem., 2009, 52, 7753-7764.

10 G. E. Buchel, I. N. Stepanenko, M. Hejl, M. A. Jakupec, B. K. Keppler and V. B. Arion, Inorg. Chem., 2011, 50, 7690-7697.

11 K. J. Kilpin, S. Crot, T. Riedel, J. A. Kitchen and P. J. Dyson, Dalton Trans., 2014, 43, 1443-1448. 
12 S. H. van Rijt, A. F. A. Peacock, R. D. L. Johnstone, S. Parsons and P. J. Sadler, Inorg. Chem., 2009, 48, 1753-1762.

13 H. Kostrhunova, J. Florian, O. Novakova, A. F. A. Peacock, P. J. Sadler and V. Brabec, J. Med. Chem., 2008, 51, 3635-3643.

14 S. D. Shnyder, Y. Fu, A. Habtemariam, S. H. van Rijt, P. A. Cooper, P. M. Loadman and P. J. Sadler, MedChemComm, 2011, 2, 666-668.

15 Y. Fu, A. Habtemariam, A. M. Basri, D. Braddick, G. J. Clarkson and P. J. Sadler, Dalton Trans., 2011, 40, 10553-10562.

16 I. Romero-Canelon and P. J. Sadler, Inorg. Chem., 2013, 52, 12276-12291.

17 A. F. A. Peacock, A. Habtemariam, R. Fernandez, V. Walland, F. P. A. Fabbiani, S. Parsons, R. E. Aird, D. I. Jodrell and P. J. Sadler, J. Am. Chem. Soc., 2006, 128, 1739-1748.

18 P. Skehan, R. Storeng, D. Scudiero, A. Monks, J. McMahon, D. Vistica, J. T. Warren, H. Bokesch, S. Kenney and M. R. Boyd, J. Natl. Cancer Inst., 1990, 82, 1107-1112.

19 I. Romero-Canelon, L. Salassa and P. J. Sadler, J. Med. Chem., 2013, 56, 1291-1300.

20 S. Y. Loh, P. Mistry, L. R. Kelland, G. Abel and K. R. Harrap, Br. J. Cancer, 1992, 66, 1109-1115.

21 M. Aureliano, World J. Biol. Chem., 2011, 2, 215-225.

22 R. Song, S. Y. Park, Y. S. Kim, Y. Kim, S. J. Kim, B. T. Ahn and Y. S. Sohn, J. Inorg. Biochem., 2003, 96, 339-345.

23 I. Romero-Canelon, A. M. Pizarro, A. Habtemariam and P. J. Sadler, Metallomics, 2012, 4, 1271-1279.

24 K. A. Price, P. J. Crouch, I. Volitakis, B. M. Paterson, S. Lim, P. S. Donnelly and A. R. White, Inorg. Chem., 2011, 50, 9594-9605.

25 K. Y. Zhang and K. K. Lo, Inorg. Chem., 2009, 48, 6011-6025.

26 H. Bayir, B. Fadeel, M. J. Palladino, E. Witasp, I. V. Kurnikov, Y. Y. Tyurina, V. A. Tyurin, A. A. Amoscato, J. Jiang, P. M. Kochanek, S. T. DeKosky, J. S. Greenberger,
A. A. Shvedova and V. E. Kagan, Biochim. Biophys. Acta, 2006, 1757, 648-659.

27 S. H. van Rijt, A. Mukherjee, A. M. Pizarro and P. J. Sadler, J. Med. Chem., 2010, 53, 840-849.

28 T. F. Chen, Y. A. Liu, W. J. Zheng, J. Liu and Y. S. Wong, Inorg. Chem., 2010, 49, 6366-6368.

29 R. Cao, J. L. Jia, X. C. Ma, M. Zhou and H. Fei, J. Med. Chem., 2013, 56, 3636-3644.

30 A. Maillet, S. Yadav, Y. L. Loo, K. Sachaphibulkij and S. Pervaiz, Cell Death Dis., 2013, 4, e653, DOI: 10.1038/ cddis.2013.185.

31 J. L. Hickey, R. A. Ruhayel, P. J. Barnard, M. V. Baker, S. J. Berners-Price and A. Filipovska, J. Am. Chem. Soc., 2008, 130, 12570-12571.

32 V. Gogvadze, S. Orrenius and B. Zhivotovsky, Semin. Cancer Biol., 2009, 19, 57-66.

33 G. M. Almeida, T. L. Duarte, P. B. Farmer, W. P. Steward and G. D. D. Jones, Int. J. Cancer, 2008, 122, 1810-1819.

34 J. G. Gong, A. Costanzo, H. Q. Yang, G. Melino, W. G. Kaelin, M. Levrero and J. Y. J. Wang, Nature, 1999, 399, 806-809.

35 J. H. Yun, Q. Zhong, J. Y. Kwak and W. H. Lee, Oncogene, 2005, 24, 4009-4016.

36 S. G. Kang, H. Chung, Y. D. Yoo, J. G. Lee, Y. I. Choi and Y. S. Yu, Curr. Eye Res., 2001, 22, 174-181.

37 E. M. Hammond, S. L. Green and A. J. Giaccia, Mutat. Res., Fundam. Mol. Mech. Mutagen., 2003, 532, 205-213.

38 Z. Estrov, S. Shishodia, S. Faderl, D. Harris, Q. Van, H. M. Kantarjian, M. Talpaz and B. B. Aggarwal, Blood, 2003, 102, 987-995.

39 A. Tyagi, R. P. Singh, C. Agarwal, S. Siriwardana, R. A. Sclafani and R. Agarwal, Carcinogenesis, 2005, 26, 1978-1987.

40 R. Palchaudhuri and P. J. Hergenrother, Curr. Opin. Biotechnol., 2007, 18, 497-503. 